\title{
SPACE PATTERN OF FOREST SPECIES AND ITS RELATIONSHIP WITH AGRICULTURAL FACTORS AGROFLORESTAL SYSTEM
}

\author{
Emanuel José Gomes de Araújo ${ }^{1 *}$, Dayane Oliveira Lima ${ }^{1}$, Rafaella De Angeli Curto², Eduardo Vinícius da \\ Silva $^{1}$, José Carlos Arthur Junior ${ }^{1}$ \\ 1*Rural Federal University of Rio de Janeiro, Department of Forestry, Seropédica, RJ, Brazil - *ejgaraujo@gmail.com; \\ dayaneoliversfg@hotmail.com; eduvini@gmail.com; josecarlosarthurjunior@gmail.com \\ ${ }^{2}$ Federal University of Mato Grosso, Institute of Agrarian and Environmental Sciences, Sinop, MT, Brazil - rafaellacurto@yahoo.com.br
}

Recebido para publicação: 02/03/2018 - Aceito para publicação: 20/09/2018

\begin{abstract}
The objective of this work was to describe the spatial distribution pattern of the arboreal and regenerating forest stratum and its relationship with edaphic factors in a multistratified agroforestry system without management. The data were obtained by means of a census of the arboreal and regenerating plants, in which the variables diameter were measured at $1.30 \mathrm{~m}$ of the soil and total height, besides the botanical identification. The plants of the arboreal stratum were grouped in diameter and height classes and the regenerating plants in height classes. In both strata, the horizontal structure indicators were estimated and the species of higher Importance Value Index (IVI) were selected to perform the spatial analysis. The K Ripley function was applied in the univariate case to test the hypothesis of complete randomness in the groups and in the arboreal and regenerating species of higher IVI. In the bivariate case, the Ripley K function was applied to test the hypothesis of complete spatial independence between groups or aggregate pattern species, with edaphic attributes. The results indicated random spatial pattern for most of the tested groups, with only the species Gliricidia sepium and Archontophoenix alexandrae with aggregate spatial pattern, up to $30 \mathrm{~m}$ distance, in the arboreal and regenerating strata, respectively. However, no spatial relationship was observed between the pattern of distribution of the species and the soil factors of agroforestry system (SAF). In general, it is concluded that edaphic factors were fundamental in the development of plants, but not for the formation of aggregates.

Key-words: Ripley K Function, spatial distribution, randomness.
\end{abstract}

\section{Resumo}

Padrão espacial de espécies florestais e sua relação com fatores edáficos em sistema agroflorestal. O objetivo deste trabalho foi descrever o padrão de distribuição espacial do estrato florestal arbóreo e regenerante e sua relação com fatores edáficos em um sistema agroflorestal multiestratificado. Os dados foram obtidos por meio de censo das plantas arbóreas e regenerantes, no qual foram mensuradas as variáveis diâmetro a 1,30m do solo e altura total, além da identificação botânica. As plantas do estrato arbóreo foram agrupadas em classes de diâmetro e de altura e as plantas regenerantes em classes de altura. Nos dois estratos, foram estimados os indicadores da estrutura horizontal e as espécies de maior Índice de Valor de Importância (IVI) foram selecionadas para realizar a análise espacial. Aplicou-se a função K Ripley, no caso univariado, para testar a hipótese de completa aleatoriedade nos grupos e nas espécies arbóreas e regenerantes de maior IVI. No caso bivariado, a função K de Ripley foi aplicada para testar a hipótese de completa independência espacial entre os grupos ou espécies de padrão agregado, com atributos edáficos. Os resultados indicaram padrão espacial aleatório para a maioria dos grupos testados, sendo apenas as espécies Gliricidia sepium e Archontophoenix alexandrae com padrão espacial agregado, até 30m de distância, nos estratos arbóreo e regenerante, respectivamente. Contudo, não foi observada nenhuma relação espacial entre o padrão de distribuição das espécies e os fatores edáficos do sistema agroflorestal (SAF). De forma geral, conclui-se que os fatores edáficos foram fundamentais no desenvolvimento das plantas, mas não para a formação de agregados.

Palavras-chaves: Função K de Ripley, distribuição espacial, aleatoriedade.

\section{INTRODUCTION}

An Agroforestry System (SAF) aims to maintain or increase productivity, preserving or improving soil fertility, in order to seek sustainability (BALBINO et al., 2011). The diversity of plant species used in SAFs forms a differentiated stratification of shoot canopy and the root system of the plants in the soil in a way that these systems aim at the logic of plant succession, the cycling of nutrients and increase biodiversity in agricultural systems (SCHUTTER, 2012). They should be done in a way that tries to reproduce to the maximum the natural formations so that the system enhances the biomass accumulation processes. In a way that the nutrients can be better utilized by the individuals, as well as the radiation and the humidity. For this, it is important to know the characteristics of each used species, their position in the system and how it relates to the other species and local edaphoclimatic factors.

FLORESTA, Curitiba, PR, v. 49, n. 2, p. 335-344, abr/jun 2019. 
Adequate management of agroforestry systems is essential in order to maintain its conformity and function over time. There is an impediment to progress on productive performance, especially in diversified systems when the monitoring and management of these areas does not occur. As a consequence, it can lead to a lack of processes control, reducing agricultural and forestry productivity and resulting in problems for rural producers. The lack of management in the system will make it heterogeneous, when this is not the intenton, losing its regularity characteristics in the spatial pattern. It arises the need to understand the behavior of plants through spatial analysis.

Among the methodologies used to describe the observations spatial pattern, we highlight the Ripley's K function (RIPLEY, 1977) which is based on counting and distance, requiring the knowledge of the coordinates (x, y) of each point. This function has been frequently applied to describe forest species spatial pattern (CAPRETZ et al., 2012; BRUZINGA et al., 2014).

The spatial pattern analysis is not recent but it has become an interesting tool in the analysis of unevenaged forests (ARAÚJO et al., 2016), and it can mainly be used to better understand the relationships between the components of more diverse agroforestry systems. This is because it allows to understand the behavior of several phenomena, such as the community structure (ARAÚJO et al., 2014) and ecological processes (CAPRETZ et al., 2012), such as competition, herbivory and seed dispersal.

However better observations can be made by relating the spatial pattern to factors such as edaphic growth, competition, reproduction, and mortality. Such factors may help to understand the possible ecological processes responsible for the pattern assumed by the plants (PALUDO et al., 2011).

The objective of this work was to describe the spatial distribution pattern of the arboreal and regenerating forest stratum and its relationship with edaphic factors in a multistratified agroforestry system without management.

\section{MATERIAL E METHODS}

\section{Area of Study and Data Collection}

The data were collected in an Agroforestry System (SAF), with an area of 3,397 $\mathrm{m}^{2}$, located in the Integrated Agroecological Production System (SIPA), Fazendinha Agroecológica Km 47, in the municipality of Seropédica, State of Rio de Janeiro, Brazil. The climate of the region is Aw type (Köppen classification), with concentrated rainfall between November and March, with an average annual precipitation of 1,213 $\mathrm{mm}$ and an average annual temperature of $23.9^{\circ} \mathrm{C}$ (CARVALHO et al., 2011). The maximum height in relation to the sea is $41.0 \mathrm{~m}$ and the minimum height is $26.3 \mathrm{~m}$ (SILVA et al., 2016). The predominant slope is less than 5\%, with Albaqualf soil (SANTOS et al., 2013).

According to Silva et al. (2016), before SAF was implanted the area had Musa sapientum L. and Carcom papaya L. monocultures fertilized only with cattle manure. The implementation of the system started in 2000 , following a multistratified arrangement. A number of species have been introduced, such as açaí (Euterpe oleracea Mart.), grumixama (Eugenia brasiliensis Lam.), citrus (Citrus sp.) and guapuruvu (Schizolobium parahyba (Jacq.) Walp.). These species were planted together with cabbage and Arachis pintoi. Some species that existed in the area were conducted, such as flamboyant (Delonin regia Bojer ex Hook). New species such as gliricidia (Gliricidia sepium (Jacq.) Walp.), jaca (Artocarpus beterophyllus Lam.), carrapeta (Guarea guidonia (L.) Sleumer), tucandeiro (Citharexylum myrianthum Cham.) and some species of Arecaceae family were planted between 2002 and 2008. More intensive management was carried out in the first two years (plantations, pruning, thinning, fertilization, harvesting and weeding). Subsequently, there are no reports of management practices used in the area.

The census of the arboreal and regenerating plants was carried out in the SAF area, with botanical identification. The diameter at $1.30 \mathrm{~m}$ of soil $(\mathrm{DBH})$ and total height $(\mathrm{Ht})$ of the arboreal individuals $(\mathrm{DBH}$ equal to or greater than $5.0 \mathrm{~cm}$ ) were measured and, in the regenerating plants, only the variable Ht was measured.

The soil was collected at depths of $0-20 \mathrm{~cm}$ and $20-40 \mathrm{~cm}$ with a soil probe $(4,5 \mathrm{~cm}$ diameter and $130 \mathrm{~cm}$ length) in 37 systematically distributed points. The soil samples were air dried, discharged and sieved with $2 \mathrm{~mm}$ mesh sieve in the Laboratory of Research and Studies in Reforestation (LAPER / UFRRJ). Subsequently the chemical analysis of the soil was carried out, in which $\mathrm{pH}, \mathrm{Al}^{3+}, \mathrm{H}^{+}+\mathrm{Al}^{3+}, \mathrm{Ca}^{2+}, \mathrm{Mg}^{2+}, \mathrm{Na}^{+}, \mathrm{K}^{+}, \mathrm{S}, \mathrm{P}$, organic carbon $(\mathrm{CO})$, organic matter content, sand, silt and clay were quantified and total nitrogen $(\mathrm{N})$ was determined.

\section{Structural Analysis}

In the tree stratum were estimated the indices that characterize the horizontal and vertical structure of the forest. For the horizontal structure, the absolute and relative indices of density, dominance, frequency and Import Value Index (IVI) were calculated. The vertical structure was stratified, based on the mean $\left(\overline{H_{t}}\right)$ and the standard deviation of the total height $\left(s_{H_{t}}\right)$ : in lower stratum $\left(H t<\overline{H_{t}}-s_{H_{t}}\right)$, medium $\left(\overline{H_{t}}-s_{H_{t}}<H t<\overline{H_{t}}+s_{H_{t}}\right)$ and 
superior $\left(H t>\overline{H_{t}}+s_{H_{t}}\right)$. The trees were grouped into eight diameter classes, with a $5 \mathrm{~cm}$ amplitude, to describe the diameter structure of the tree stratum $(5+10 ; 10+15 ; 15+20 ; 20-25 ; 25+30 ; 30-35 ; 35-40$ and $>40 \mathrm{~cm})$.

The regenerating plants were grouped into three height classes: recruited plants $\left(H t<\overline{H_{t}}-s_{H_{t}}\right)$, not established $\left(\overline{H_{t}}-s_{H_{t}}<H t<\overline{H_{t}}+s_{H_{t}}\right)$ and established $\left(H t>\overline{H_{t}}+s_{H_{t}}\right)$. The same phytosociological indexes were also obtained for the analysis of the horizontal structure, except absolute and relative dominance.

In the soil variables, the mean values of the collection points at each depth were obtained and these were divided into the denominated low-value (below-average) and high-value (above-average) intervals.

\section{Spatial Analysis}

The spatial pattern of the tree stratum and of regeneration was analyzed by means of the univariate and bivariate Ripley's K function, which consists of a counting and distance method, using the coordinates $(x, y)$ of each tree/plant, allowing to evaluate the spatial distribution at different scales. Through the univariate Ripley's K function, it was possible to test the hypothesis of Complete Spatial Randomness (CSR), in which it was investigated whether the pattern of species spatial distribution behaves in an aggregate, random or regular way. The bivariate Ripley's K function, in turn, allowed to analyze the hypothesis of Complete Spatial Independence (CSI), which informs if the relationship between plants and edaphic factors is one of attraction, independence or inhibition.

The tree stratum analysis was performed in eight diameter classes, three height classes and four species with the highest Import Value Index. For the regenerating stratum, the analysis was performed in the three height classes and for the two species with the highest Importance Value Index, using the univariate analysis. The groups that presented aggregate pattern were related to edaphic factors through bivariate analysis.

The relationships between pairs of events (pairs of points) were evaluated every $5 \mathrm{~m}$ (s) of distance, with a maximum distance of $100 \mathrm{~m}$ considered. This is because, in rectangular areas, the Ripley's K-function estimator is not tied to distances less than half of the smaller side of the rectangle (CAPRETZ et al., 2012).

In univariate and bivariate cases, 1,000 Monte Carlo simulations were performed to construct the reliable envelopes, with $(1 /(1+\mathrm{m})) \times 100 \%$ probability. For this, the estimator of the K function in the univariate case is based on the isotropic edge correction according to the formulation $\widehat{K}(s)=\frac{1}{\hat{\lambda}_{n}} \sum_{i=1}^{n} \sum_{j=1}^{n} W_{I}^{-1}\left(x_{i}, x_{j}\right) I\left(\| x_{i}-\right.$ $x_{j} \|<s$ ), for $\mathrm{i} \neq \mathrm{j}$ and $\mathrm{s}>0$ (RIPLEY, 1977). Where: $n$ is the number of trees in the study region; $x_{i}-x_{j}$ the coordinates of the map points; $\left\|x_{i}-x_{j}\right\|$ is the Euclidean distance between locations $x_{i}$ e $x_{j}$; $\mathrm{s}$ is an arbitrary vector of distances; $\hat{\lambda}_{n}=n /\|A\|$ is the number of trees divided by the area of the study region, being an unbiased estimator of the intensity of the process; $W_{I}\left(x_{i}, x_{j}\right)$ is the isotropic edge correction function, which represents the proportion of the circle with center at $x_{i}$ and with radius $\left\|x_{i}-x_{j}\right\|$ that is outside the study region, the function being defined for any convex polygon; $\mathrm{I}(\mathrm{U})$ is an indicator function that assumes the value 1 (one) whenever the condition $\mathrm{U}$ is true and 0 (zero) when false.

The use of the transformed function $\hat{L}(s)=\sqrt{\widehat{K}_{s} / \pi}-s$ was applied in the graphical interpretation of Ripley's K function (CAPRETZ et al., 2012). Where: $\hat{L}(s)$ is the value of the $\widehat{K}_{s}$ function transformed; $\widehat{K}_{s}$ is the estimator of Ripley's function in the univariate case and $\mathrm{s}$ is a vector of distances.

For the bivariate function $\mathrm{K}$, also called the cross function, it becomes possible to investigate the spatial relationship between two groups of events. The estimation of bivariate K-function was done in an analogous way to the univariate function (CAPRETZ et al., 2012) $\widehat{K_{12}}(s)=\frac{1}{\hat{\lambda}_{1} \hat{\lambda}_{2}} \sum_{i=1}^{n} \sum_{j=1}^{n} W_{I}^{-1}\left(x_{1 i}, x_{2 j}\right) I\left(\left\|x_{1 i}-x_{2 j}\right\|<s\right)$, for $\mathrm{i} \neq \mathrm{j}$ e $\mathrm{s}>0$. In which: $\hat{\lambda}_{1}=n_{1} /\|A\|$ is the unbiased estimator of the intensity of the first process; $\hat{\lambda}_{2}=$ $n_{2} /\|A\|$ is the unbiased estimator of the intensity of the second process; $W_{I}\left(x_{1 i}, x_{2 j}\right)$ is the isotropic correction function of the tree-centered border of the first process and $\mathrm{I}(\mathrm{U})$ is an indicator function centered on the trees of the first process.

After the simulations, were defined the reliability interval, which delimits the region of acceptance of the hypothesis $\left(\mathrm{H}_{0}\right)$ of the pattern spatially random (univariate case) or independent (bivariate case). In the construction of this interval, the minimum and maximum values of $\mathrm{K}$ obtained in the simulations for each distance $\mathrm{s}$ were stored. When the estimated values of the $\mathrm{K}$ function exceeded the upper limit of the envelope, the standard was aggregation (univariate) or attraction (bivariate). When they exceeded the lower limit, the pattern was of regularity (univariate) or repulsion (bivariate) and when they remained inside the envelopes, the pattern was random (univariate) or independent (bivariate). All analysis were performed in software R.

FLORESTA, Curitiba, PR, v. 49, n. 2, p. 335-344, abr/jun 2019. 


\section{RESULTS}

There were found 43 tree species, five of which were not identified, and 95 regenerating (non-arboreal) species, of which 44 were unidentified. In plants where it was not possible to perform botanical identification, such plants were classified as Morphospecies. The phytosociological parameters corresponding to the horizontal structure for the 10 species with the highest Import Value Index (IVI) in tree and regenerative plants are presented in Table 1.

Table 1. Horizontal structure of the arboreal and regenerator stratum of a Multistratified SAF, Seropédica, RJ. Tabela 1. Estrutura horizontal do estrato arbóreo e regenerante de um SAF Multiestratificado, Seropédica, RJ.

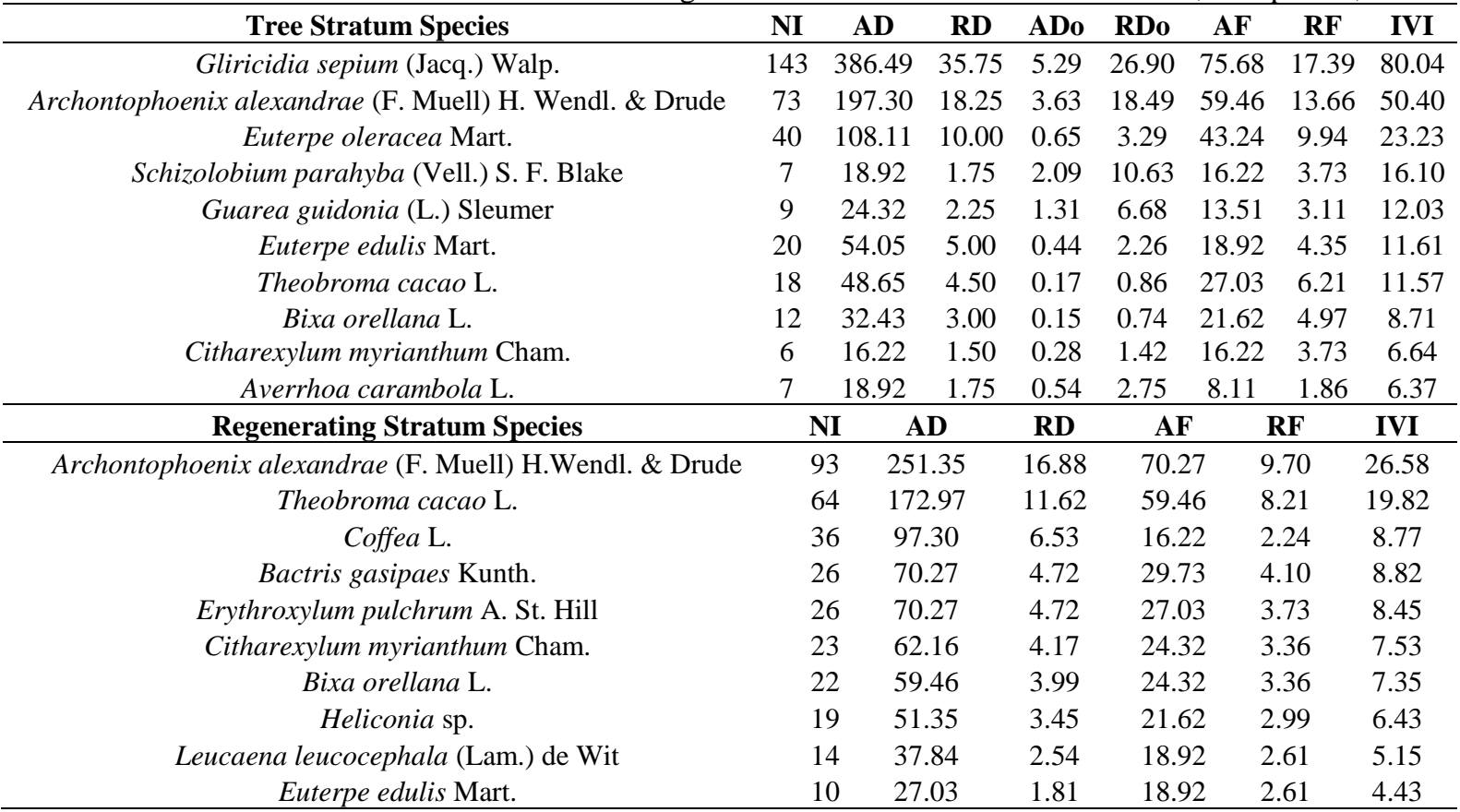

Legend: $\mathrm{NI}=$ number of individuals, $\mathrm{AD}=$ absolute density (individuals $/ \mathrm{ha}), \mathrm{ADo}=$ absolute dominance $\left(\mathrm{m}^{2} / \mathrm{ha}\right) \mathrm{AF}=\mathrm{absolute}$ frequency $(\%), \mathrm{RD}=$ relative density $(\%), \mathrm{RDo}=$ relative dominance $(\%) \mathrm{RF}=$ relative frequency $(\%)$ e IVI = Importance Value Index

The spatial pattern was analyzed for all species groups, considering all the plants, divided into arboreal strata (Figure 1A) and regenerating (Figure 1B), where the estimated values of the univariate $\mathrm{K}$ function extrapolated the lower limits of the envelopes of confidence, indicating the rejection of the hypothesis of complete spatial randomness, being verified regular pattern. For the tree species were analyzed the four of the highest IVI (Figure $1 \mathrm{C}$ to $1 \mathrm{~F}$ ), in which, in general, the hypothesis of complete spatial randomness was accepted, except for the species Gliricidia sepium. As for the distribution of tree individuals in height classes, a variation was observed between the random and regular patterns in the three evaluated strata (Figure 1G to 1I). And for the distribution of tree individuals in diameter classes (Figure 16-a 1L), a random spatial pattern up to $50 \mathrm{~m}$ pattern and regular from there in the smallest size class (Figure $1 \mathrm{~J}$ ) was observed, ranging from $20 \mathrm{~m}$ to $40 \mathrm{~m}$ for the intermediate class (Figure $1 \mathrm{~K}$ ) and completely random at all distances to the upper class (Figure 1L).
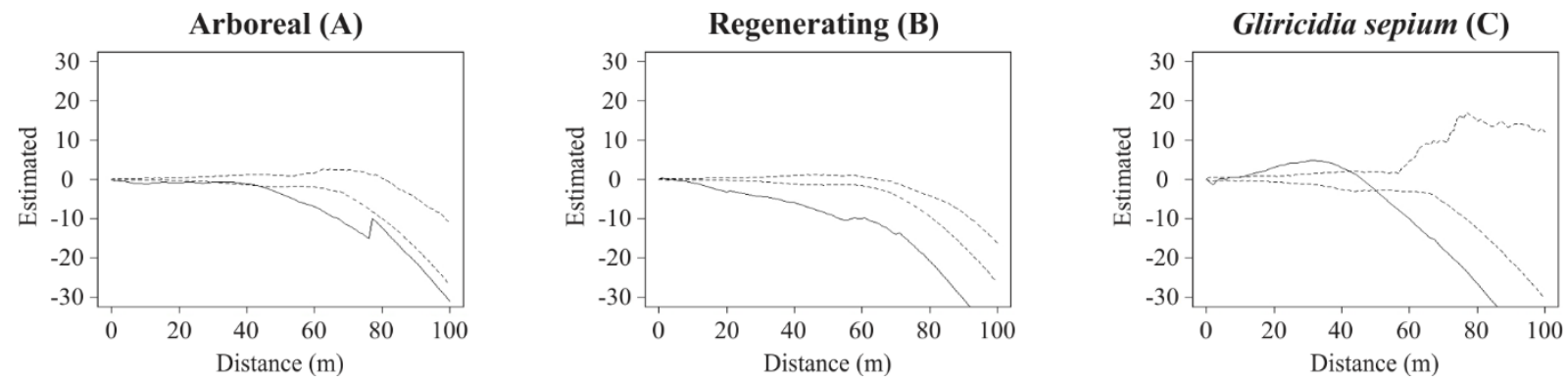

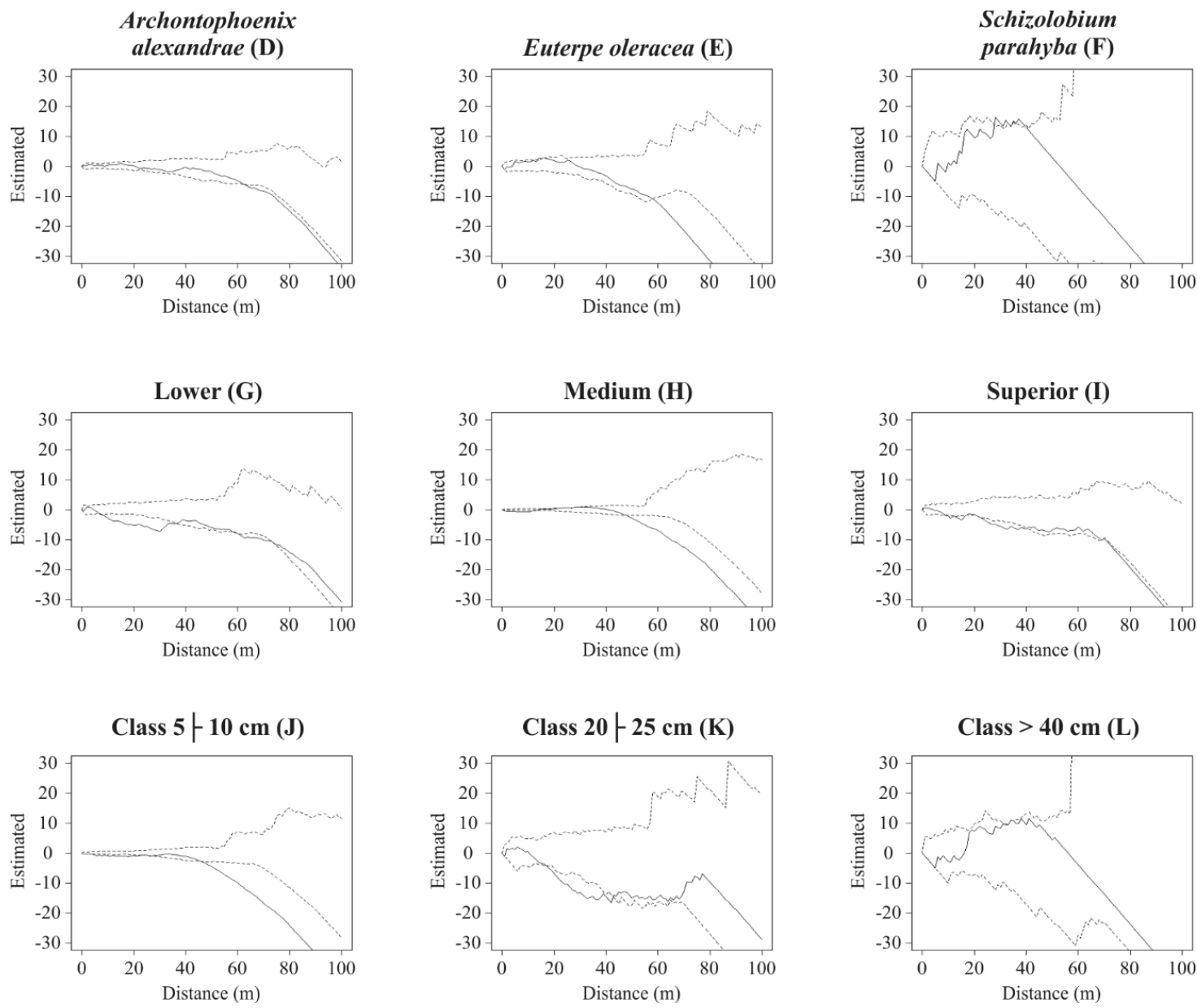

Figure 1. Estimated values (continuous line) and confidence limits (dashed lines) of the univariate Ripley $\mathrm{K}$ function for the arboreal stratum (A) and regenerant (B) considering all groups of species occurring, and for tree species of higher IVI (C, D, E, F), grouped in strata of height $(\mathrm{G}, \mathrm{H}, \mathrm{I})$, and grouped in diameter classes (J, K, L), in a Multistratified SAF Seropédica, RJ.

Figura 1. Valores estimados (linha contínua) e limites de confiança (linhas tracejadas) da função K de Ripley univariada para o estrato arbóreo (A) e regenerante (B) considerando todos os grupos de espécies ocorrentes, e para espécies arbóreas de maior IVI (C, D, E, F), agrupadas em estratos de altura (G, H, I), e agrupadas em classes de diâmetro (J, K, L), em um SAF Multiestratificado Seropédica, RJ.

For the univariate analysis of natural regeneration, the species Archontophoenix alexandrae, of higher IVI (Figure 2A), presented aggregated spatial pattern up to approximately 40m distance, and for the separation of the regenerating plants in height classes (Figure $2 \mathrm{C}$ to $2 \mathrm{E}$ ), a regular spatial pattern was observed, since the values of the estimated $\mathrm{K}$ function exceeded the lower limits of the confidence intervals.
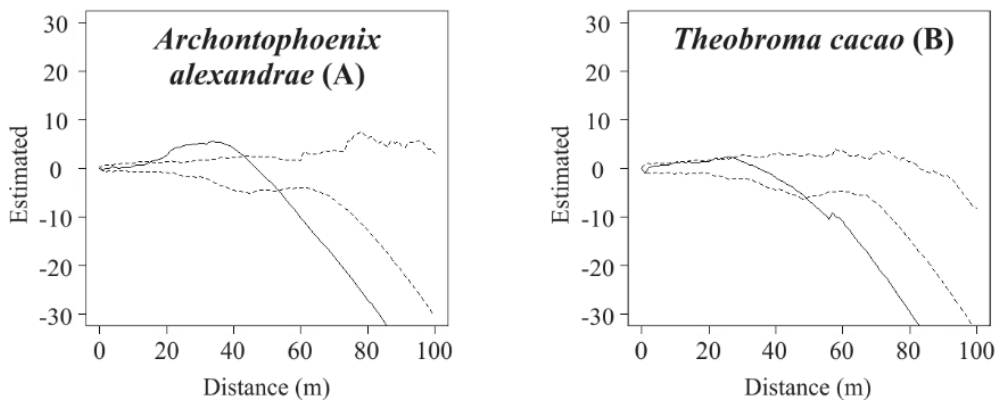

FLORESTA, Curitiba, PR, v. 49, n. 2, p. 335-344, abr/jun 2019.

Araújo. E. J. G. et.al.

ISSN eletrônico 1982-4688

DOI: $10.5380 /$ rf.v49 i 2.58207 

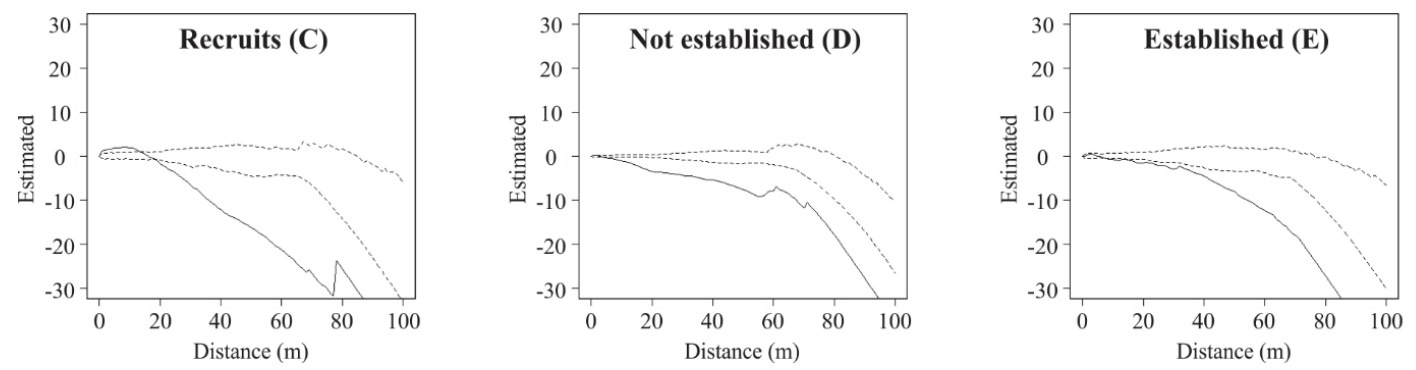

Figure 2. Estimated values (continuous line) and confidence limits (dashed lines) of the univariate Ripley $\mathrm{K}$ function for regenerating species of higher IVI (A, B) and grouped into recruitment classes $(C, D, E)$, in a multi-layered SAF, Seropédica, RJ.

Figura 2. Valores estimados (linha contínua) e limites de confiança (linhas tracejadas) da função K de Ripley univariada para as espécies regenerantes de maior IVI (A, B) e agrupadas em classes de recrutamento (C, D, E), em um SAF Multiestratificado, Seropédica, RJ.

By means of the univariate analysis, the species Gliricidia sepium, among the trees and Archontophoenix alexandrae among the species that occurred in the regeneration were the only ones in which aggregation was observed, with such a pattern up to $40 \mathrm{~m}$ distance approximately. This was determinant for these species to be chosen for bivariate analysis in relation to soil nutrients, in which they portrayed possible relationships between the pattern of aggregation and the search for nutrients necessary for individuals to establish themselves (Figure 3).
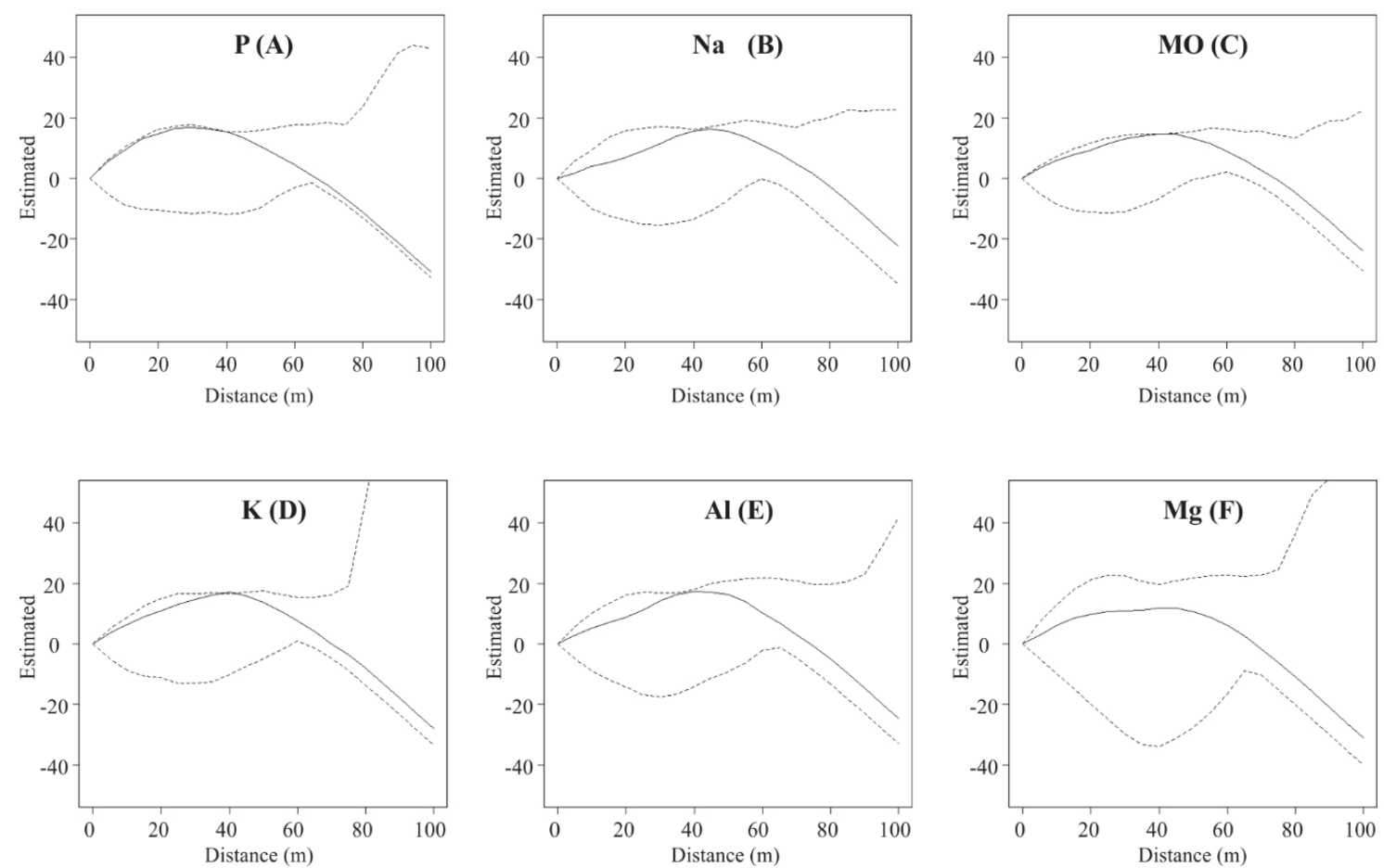

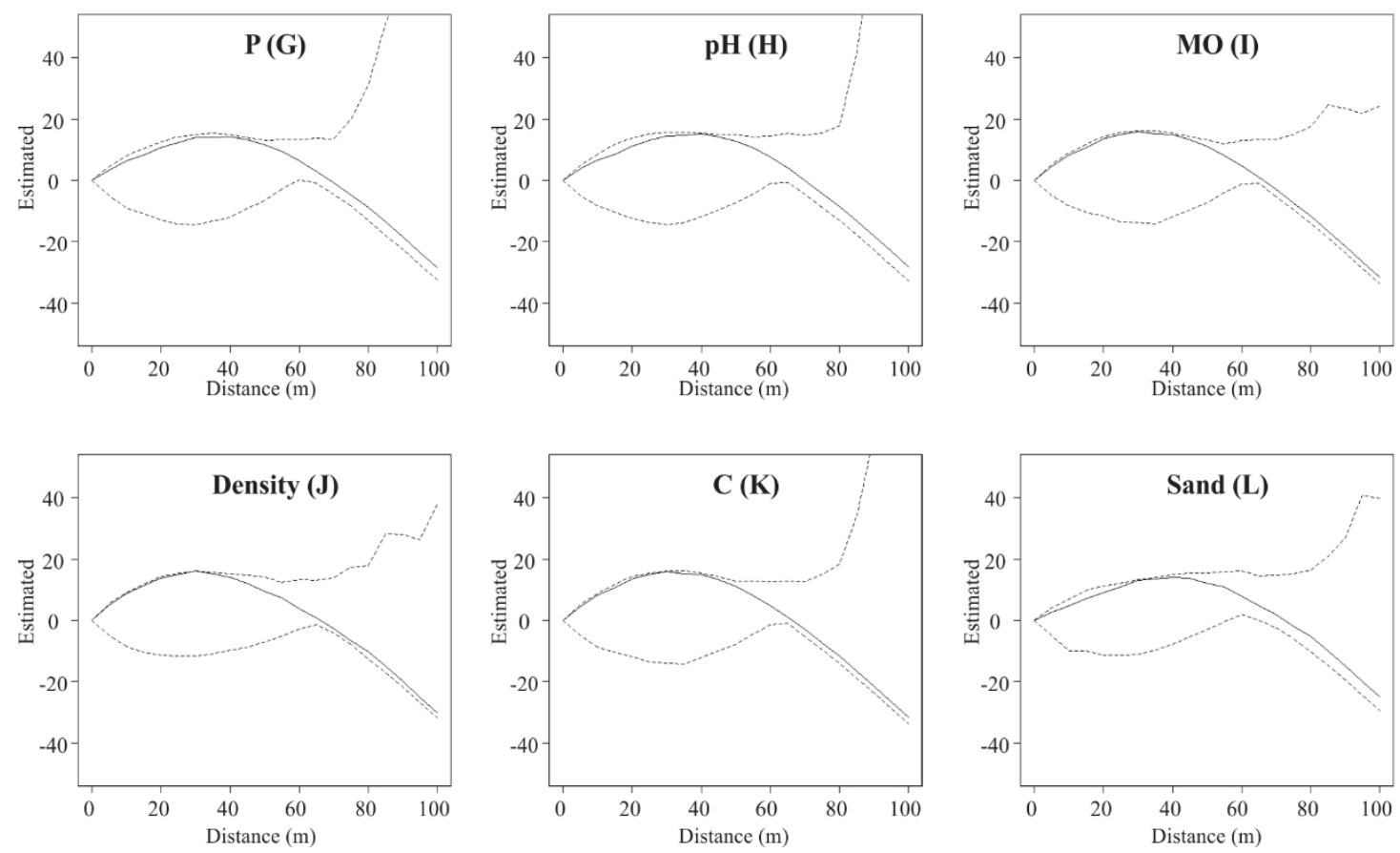

Figure 3. Ripley's K function (bounded lines) and confidence limits (dashed lines) between tree species G. sepium and above-average edaphic variables (AF) and between regenerating A. alexandrae and edaphic variables (GL) below the average, in a Multistratified SAF, Seropédica, RJ.

Figura 3. Valores estimados (linha contínua) e limites de confiança (linhas tracejadas) da função K de Ripley bivariada entre a espécie arbórea G. sepium e variáveis edáficas (A-F) acima da média e entre a espécie regenerante $A$. alexandrae e variáveis edáficas (G-L) abaixo da média, em um SAF Multiestratificado, Seropédica, RJ.

\section{DISCUSSION}

There are few studies related to the characterization of multistratified SAF through phytosociology. In these systems the study of phytosociology aims to better understand the designs and the function that the species exert in each situation and they have the importance for the replication of those systems in other properties. Among the most used phytosociological parameters are those involving the analysis of horizontal and diametric structure and the indices that analyze the diversity and heterogeneity of vegetation. The species of highest IVI for the tree stratum were Gliricidia sepium (386 plants.ha ${ }^{-1}$ ), Archontophoenix alexandrae (197 plants.ha $\left.{ }^{-1}\right)$, Euterpe oleracea (108 plants.ha $\left.{ }^{-1}\right)$ and Schizolobium parahyba $\left(18\right.$ plants.ha $\left.{ }^{-1}\right)$ (Table 1)

Although the species Schizolobium parahyba presented a low absolute density in relation to other species, for example the Euterpe edulis (Table 1), the diametric size of the trees generated a significant basal area when compared to the other species, increasing its dominance in the area, and consequently its IVI. $67.44 \%$ of the total species present had a relative density of less than $1 \%$, indicating a predominance of few species in relation to the others. This is proven when considering the four species of higher IVI in a single group, in which they correspond to $65.75 \%$ of the total tree plant in the area and are therefore selected for spatial analysis.

It was observed in the regenerating stratum that $81.05 \%$ of the species have a relative density of less than $1 \%$, also indicating the dominance of a few species in this stratum. The most important regenerating species were Archontophoenix alexandrae (251 plants.ha ${ }^{-1}$ ) and Theobroma cacao (172 plants.ha ${ }^{-1}$ ) (Table 1), and they were also the ones presenting more homogeneous spatial distribution, occurring in 70.27 and $59.46 \%$, respectively, of the subunits allocated to carry the census out.

Considering the spatial pattern for all species groups (Figure 1A and 1B), for both tree stratum and regenerating, the estimated values of the $\mathrm{K}$ function extrapolated the lower limits of the envelopes of confidence, indicating the rejection of the hypothesis of complete spatial randomness, being verified regular pattern, which indicates that the plants tend to repel each other whether they occur in the area. This is because, according to Souza and Silva (2006), in populations with a regular pattern, the plants are more evenly spaced than in the random pattern and the occurrence of one individual prevents the next one (repulsion).

FLORESTA, Curitiba, PR, v. 49, n. 2, p. 335-344, abr/jun 2019.

Araújo. E. J. G. et.al.

ISSN eletrônico 1982-4688

DOI: $10.5380 /$ rf.v49 i 2.58207 
Concerning the spatial distribution of regenerating plants, Crawley (1986) states that seed "rain" from adult individuals reaches the soil surface in an aggregate pattern, so they can remain in place and be established there or be brought to other sites by some dispersing agent. This causes the spatial distribution tendency of regenerations to be aggregated, being also random and rarely regular. Despite this, Capretz et al. (2012) verified a random pattern in the largest diametric classes for Ombrophilous forest species.

However, in the arboreal and regenerating strata, the regular distribution pattern, which is considered rare, was observed. This can be explained by the fact that SAFs are planted areas and not of a natural order and therefore tend to have a regular distribution where their locations in the area are not influenced by ecological processes such as seed dispersal and herbivory. Thus, despite the great variability of species, in multistratified SAF a large part comes from the implantation. It should be noted that in the two situations in question, the analysis was made considering all species, each of which has a seed dispersal syndrome which may influence the final spatial pattern.

In this way, the ideal is to verify the spatial pattern by species or groups of species. Thus, for the tree species analyzed, the four with the highest IVI generally accepted the hypothesis of complete spatial randomness, since the line indicating the estimated values of $\mathrm{K}$ for each species remained within the trusted envelope (Figure $1 \mathrm{C}, 1 \mathrm{D}, 1 \mathrm{E}$ and $1 \mathrm{~F})$. Even in the case of planting where the expected spatial pattern is the regular one, the randomness between plants is due to lack of management in the area.

For Gliricidia sepium up to approximately 40 meters away an aggregate pattern was observed, indicating the spatial dependence of the individuals (Figure 1C). Such a result could be an evidence that the species was not implanted in SAF since its pattern does not tend to regular, so its occurrence is mainly due to regeneration. For Silva et al. (2009), the formation of aggregate patterns is related to seed dispersal at close range, so that the seedlings remain close to the mother plant. After 50 meters of distance the pattern found was the regular one, that according to Ricklefs and Miller (2000), derives from the interaction between the individuals, being uncommon in populations and vegetal communities, restricting it to the species that present inhibiting composites of other individuals in its neighborhood. But as quoted, it is due to the fact that a part of the area has been implanted.

The aggregation found among individuals of the species Gliricidia sepium, is a reflection of the current situation of abandonment of the area. With the lack of management over time, the individuals end up establishing themselves in a disordered way, very close to each other and without the characteristics of the spacing used in the implantation of SAFs. When there are dense local aggregations, and the demand for resources increases considerably, intraspecific competition occurs. Thus, in situations such as that found it is recommended to apply management practices which return the structure of the SAF, by means of the removal/thinning of some species.

The individuals of the species Euterpe oleracea presented basically the same behavior of Archontophoenix alexandrae, where the value of $\mathrm{K}$ did not exceed the upper limit of the envelope, depicting randomness between their plants until approximately $60 \mathrm{~m}$ and after that it was observed the regular pattern. The $\mathrm{K}$ values found for the species Schizolobium parahyba showed random pattern at all distances along the confidence envelope.

The individuals of a population considered have a random pattern when the position of each individual is independent of the others, in such a way that anyone has an equal and independent chance of occurring at any point in the area considered (SOUZA; SILVA, 2006). Several factors can determine the spatial distribution pattern of a species, such as reproductive aspects (BRUZINGA et al., 2014), where the spatial independence between individuals can be explained by the dispersion of the seeds being anemocoric.

The species Archontophoenix alexandrae and Schizolobium parahyba present pattern of anemocoric and zoocoric dispersion, respectively, which in a way justifies the observed spatial pattern. In general, for the four species analyzed different behavior of the normal pattern naturally expected for a SAF was observed, since the area has been unmanaged since its implantation practically in the middle of the year 2000. Thus, the natural regeneration processes and occasionally antropic processes that occurred over time possibly led to the predominance of the random pattern. Therefore, it can be verified that the area has undergone succession process, resembling a natural forest, whose process tends to intensify if it continues without management. Despite this, a question to be considered is that the number of individuals analyzed in each group influenced the definition of the upper and lower limits of the $\mathrm{K}$ function. When analyzing a certain number of individuals for each distance, these can cause the limit be greater or smaller, according to the number of trees in each class.

Regarding the distribution of tree individuals in height classes, a variation between the random and regular patterns in the three strata was observed, in which the behavior of the lower stratum $\left(H t<\overline{H_{t}}-s_{H_{t}}\right)$ was observed until approximately $30 \mathrm{~m}$ distance, following a regular spatial pattern (Figure $1 \mathrm{G}$ ), characterizing that individuals of smaller size tend to occur inhibiting the presence of others. Such a result was contrary to that obtained by Capretz et al. (2012) who observed that trees in the smaller classes (where young trees are probably included) show aggregation and that trees of larger classes are prone to random patterns.

The average stratum showed tendency to the aggregation pattern up to approximately 40 meters away (Figure 1H), differently from the expected pattern, and shortly thereafter a regular distribution, expected for this 
type of system, was evidenced. The tendency to aggregate in the first few meters could possibly be explained by dispersions occurring soon after planting of the SAF, where the species were dispersed by wind or animals, and thus spots occurred tending to form aggregates.

For the analysis performed by diameter class of the arboreal stratum, the random spatial pattern was observed and in some cases regular, for most size classes (Figure 1J, 1K, 1L). Araújo et al. (2014) argue that variations in the pattern of distribution may be related to the arboreal size of the individuals, since younger individuals tend to occur closer to each other, forming aggregates and as they grow competition increases and few reach the larger diameters, becoming more distanced from each other, which leads to a random distribution. This same behavior was verified for tree species in natural forests (CAPRETZ et al., 1669, 2012).

A regular spatial pattern was observed for the smallest size classes (Figure 1J). Ludwig and Reynolds (1988) argue that in this type of distribution, negative interactions between individuals (such as competition for food or space) result in uniform spacing between plants. Thus, the lack of management over time, and its consequent competition, is the main reason for such behavior.

Only the diametric class that encompasses individuals with DBH between 30 and $40 \mathrm{~cm}$ was the one that presented aggregated spatial pattern between 20 and $40 \mathrm{~m}$ distance. Because they are dominant plants, soil conditions can be a factor that contributed to the development of these plants in the same place, characterizing the aggregation. This result contributes to and strengthens the idea that site conditions, especially soil characteristics, may influence the spatial pattern of plants.

For the univariate analysis of natural regeneration, the species Archontophoenix alexandrae (Figure 2A) presented aggregate spatial pattern up to approximately $40 \mathrm{~m}$ distance. In secondary forests it can be found a high density of trees per hectare, represented by small trees that inhabit the first strata of the vegetation and young individuals of large trees of the forest canopy. This means that there is a marked participation of these smaller individuals forming small dense spots on the vegetation and providing an aggregated spatial distribution or tending to aggregation. Another important aspect is that the aggregation may be from the dispersal of the seeds of the mother plant, which may concentrate at a given spot forming small patches of plants of the same species.

The knowledge of the distribution pattern of seed and species production is fundamental in decision making in the silvicultural management to be applied in the area. In this way, the spatial analyzes using the $\mathrm{K}$ function contribute to indicate the conditions of a SAF in relation to the need to carry out management practices.

The analyzes carried out in this study (Figure 2A and 2B) confirmed the need for management interventions, mainly regarding the aggregation presented by the individuals of Archontophoenix alexandrae, which probably happen due to the competition of the individuals by nutrients, fact due to the lack of monitoring and knowledge of the processes that have occurred since the implementation of the system up to the current situation.

As for the arboreal stratum, the separation of regenerating plants into height classes provided a regular spatial pattern (Figure 2C, 2D and 2E). Only a slight aggregation is perceived between recruits (Figure 2C) up to approximately $15 \mathrm{~m}$ apart. These are smaller plants and probably come from heavier seeds, which when dispersed by the mother plant, tend to develop together forming the aggregates. Over time, due to the processes of competition for local resources, they tend to assume a pattern of repulsion as they become unstable and established plants.

For all cases of bivariate analyzes using Ripley's K function the values did not exceed the limits of the reliable envelopes (Figure 3), indicating spatial independence between the plants of the species Gliricidia sepium and Archontophoenix alexandrae with the nutrients present in the soil, allowing the acceptance of the hypothesis of complete spatial independence. This fact can be explained by individuals' need for nutrients for growth and reproduction, some being essential and others just as a complement to their development. Some species may need few nutrients; however, they are essential in their quantity.

The Ripley's K function in the bivariate case generates results of how two events in the same area are related and in what way one event spatially reacts in the presence of another. Areas that show great variation in floristic composition can be ordered to form a diagram of the analyzed region and thus serve as an indication of which edaphic factors would be generating this variation along the gradient.

Soil variations and toposequence are accompanied by variations in the floristic composition and structure of the plant community. This can be observed in the nutritional state of the vegetation, being these variations the vegetation responses to changes in soil nutrient availability (MORENO et al., 2008). However, the analysis carried out associating soil nutrients and individuals of the species showed that the soil variations had little influence on the spatial distribution of the plants, i.e., the way in which the individuals are allocated in the system is not linked to the amount of soil nutrients. Thus, it can be inferred that the development of the plants spatially in the area is more related to the seed dispersal syndrome.

FLORESTA, Curitiba, PR, v. 49, n. 2, p. 335-344, abr/jun 2019.

Araújo. E. J. G. et.al.

ISSN eletrônico 1982-4688

DOI: $10.5380 /$ rf.v49 i 2.58207 


\section{CONCLUSIONS}

- The predominant spatial pattern in arboreal and regenerating plants is the random pattern. This pattern probably occurs due to the lack of management during the development of the agroforestry system when it comes to tree plants, and by the seed dispersal syndrome that occurs by the wind in a random way when it comes to regenerating plants.

- As for the spatial relationship between tree and regenerative plants with edaphic factors, it was verified that, for the area under study, these factors do not interfere in the spatial distribution of the individuals, allowing the acceptance of the hypothesis of complete spatial independence.

- The current conditions of spatial distribution of arboreal and regenerating plants provide greater competition for soil resources, so soil factors were fundamental in the development of plants, but not in the formation of aggregates.

\section{REFERENCES}

ARAÚJO, E. J. G.; DAVID, H. C.; PÉLlICO NETTO, S.; MORAIS, V. A.; SCOLFORO, J. R. S. Padrão espacial de espécies arbóreas em fragmento de Floresta Estacional Semidecidual. Revista Ciências Agrárias, v. 57, n. 2, p. 166-171, 2014.

ARAÚJO, E. J. G.; PÉlliCO NETTO, S.; MACHADO, S. A.; DALlA CORTE, A. P.; SCOLFORO, J. R. S.; DAVID, H. C.; MORAIS, V. A. Função K de Ripley e índice de Moran na distribuição espacial da regeneração natural da candeia em áreas manejadas. Revista Brasileira de Biometria, Lavras, v.34, n.3, p.468-488, 2016.

BALBINO, L. C.; CORDEIRO, L. A. M.; MARTÍNEZ, G. B. Contribuições dos Sistemas de Integração LavouraPecuária-Floresta (iLPF) para uma Agricultura de Baixa Emissão de Carbono. Revista Brasileira de Geografia Física, n. 5, p. 1014-1026, 2011.

BRUZINGA, J. S.; OLIVEIRA, M.L.R. de; NOGUEIRA, G.S.; PEREIRA, I.M.; LEITE, H.G.; MACHADO, E.L.M. Métodos de amostragem para quantificar indivíduos adultos do pequi Caryocar brasiliense Cambess. Ciência Rural, v.44, n.8, p. 1341-1347, 2014.

CAPRETZ, R. L., BATISTA, J. L. F., SOTOMAYOR, J. F. M., CUNHA, C. R., NiCOLETTI, M. F. \& RODRIGUES, R. R. Padrão espacial de quatro formações florestais do estado de São Paulo, através da função K de Ripley. Ciência Florestal, v. 22, p. 551-565, 2012.

CARVALHO, D. F.; SILVA, D. G.; SOUZA, A. P.; GOMES, D. P.; ROCHA, H. S. Coeficientes da equação de Angström-Prescott e sua influência na evapotranspiração de referência em Seropédica, RJ. Revista Brasileira de Engenharia Agrícola, v. 15, n. 8, p. 108-116, 2011.

CRAWLEY, M. J. Plant Ecology. Oxford: Blackwell Scientific Publications, 1986. 496 p.

LUDWIG, J.A.; REYNOLDS, J.F. Statistical ecology. New York: John Wiley, 1988. 337p.

MORENO, M. I. C.; SCHIAVINI, I.; HARIDASAN, M. Fatores edáficos influenciando na estrutura de fitofisionomias do Cerrado. Caminhos de Geografia, Uberlândia v. 9, n. 25, p. 173-194, 2008.

PALUDO, G. F.; MANTOVANI, A.; REIS, M. S. Regeneração de uma população natural de Araucaria angustifolia (Araucariaceae). Árvore, Viçosa-MG, v.35, n.5, p.1107-1119, 2011.

RICKLEFS, R.E.; MILLER, G. L. Ecology. 4th. Edition. W.H. Freeman and Company. New York, 2000.

RIPLEY, B. D. Modelling spatial patterns. Jour. of the Royal Statistic Society, v.39, p.172-212, 1977.

SANTOS, H. G.; JACOMINE, P.K.T.; ANJOS, L.H.C.; OLIVEIRA, V.A.; LUMBRERAS, J.F.; COELHO, M.R.; ALMEIDA, J. A.; CUNHA, T. J. F.; OLIVEIRA, J. B. Sist. Bras. Classificação de Solos. Embrapa, 2013. 353p.

SILVA, C. S.; PEREIRA, M. G.; DELGADO, R. C.; SILVA E. V. Spatialization of soil chemical and physical attributes in an agroforestry system, Seropédica, Brazil. Cerne, v. 22, n. 4, p 407-414, 2016.

SILVA, K. E.; MARTINS, S. V.; SANTOS, N. T.; RIBEIRO, C. A. A. S. Padrões espaciais de espécies arbóreas tropicais. In: MARTINS, S. V. (Ed.). Ecologia de florestas tropicais do Brasil. Viçosa: UFV, 2009. p. 216 - 244.

SCHUTTER, O. Agroecology, a tool for the realization of the right to food. In: LICHTFOUSE, E. Agroecology and Strategies for Climate Change. Spring. 2012. p. 1-16.

SOUZA, V. L.; SILVA, O. A. Estrutura e distribuição espacial de árvores de uma população de Stryphnodendron adstringens (Mart). Coville em cerrado da Reserva Biológica e Estação Experimental de Mogi Guaçu, Estado de São Paulo, Brasil. Holos Environment, v.6, 2006. 